\title{
Occurrence of polar mesosphere summer echoes at very high latitudes
}

\author{
M. Zecha ${ }^{1}$ and J. Röttger ${ }^{2}$ \\ ${ }^{1}$ Leibniz-Institut für Atmosphärenphysik, Kühlungsborn, Germany \\ ${ }^{2}$ EISCAT-CAWSES-Copernicus and Max-Planck Institute for Solar System Research, Katlenburg-Lindau, Germany
}

Received: 7 November 2007 - Revised: 16 December 2008 - Accepted: 17 December 2008 - Published: 30 March 2009

\begin{abstract}
Observations of polar mesosphere summer echoes (PMSE) have been carried out during the summer periodes 1999-2001 and 2003-2004 at the very high latitude of $78^{\circ} \mathrm{N}$ using the SOUSY Svalbard Radar $(53.5 \mathrm{MHz})$ at Longyearbyen. Although the measurements could not be done continuously in these seasons, PMSE have been detected over more than $6600 \mathrm{~h}$ of $9300 \mathrm{~h}$ of observation time overall. Using this data base, particular PMSE occurrence characteristics have been determined. PMSE at Svalbard appear from the middle of May to the end of August with an almost permanent total occurrence in June and July. Diurnal variations are observable in the height-depend occurrence rates and in PMSE thickness, they show a maximum around 09:00-10:00 UTC and a minimum around 21:0022:00 UTC. PMSE occur nearly exclusively between a height of $80 \mathrm{~km}$ and $92 \mathrm{~km}$ with a maximum near $85 \mathrm{~km}$. However, PMSE appear not simultaneously over the entire height range, the mean vertical PMSE extension is around 4-6 km in June and July. Furthermore, typically PMSE are separated into several layers, and only $30 \%$ of all PMSE are single layers. The probability of multiple layers is greater in June and July than at the beginning and the end of the PMSE season and shows a marked 5-day-variation. The same variation is noticeable in the seasonal dependence of the PMSE occurrence and the PMSE thickness. We finally discuss potential geophysical processes to explain our observational results.
\end{abstract}

Keywords. Atmospheric composition and structure (Aerosols and particles; Middle atmosphere - composition and chemistry) - Meteorology and atmospheric dynamics (Climatology)

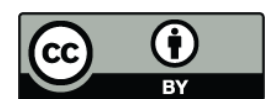

Correspondence to: M. Zecha (zecha@iap-kborn.de)

\section{Introduction}

Strong mesospheric VHF radar echoes are observed during summer months at polar latitudes and with a lower occurrence rate at middle latitudes as well. They are called polar mesosphere summer echoes (PMSE) and mesosphere summer echoes (MSE), respectively. The phenomenon of these radar echoes is observed more or less sporadically for nearly three decades since the first detections in mid latitudes (Czechowsky et al., 1979) and polar latitudes (Ecklund and Balsley, 1981). The latter authors first pointed out their particular traits, which discriminate them from standard VHF radar echoes resulting from backscatter by ionisation irregularities created by neutral turbulence in the mesosphere.

In order to create backscatter, irregularities at the scale of half the radar wavelength (Bragg scale) need to be present. At the PMSE altitudes, the spatial scale of typically used VHF radars is in the viscous subrange of neutral turbulence (e.g. $3 \mathrm{~m}$ for observations at $50 \mathrm{MHz}$ ). Consequently, these irregularities are destroyed by viscous damping, making backscatter of this kind undetectable. However, the ionisation irregularity destruction is prevented when the diffusion of electrons is reduced in the presence of heavy aerosol or ice particles. This process shifts the turbulence-driven spectrum of the ionisation irregularities to markedly shorter scales than those observed in the neutral turbulence (Kelley et al., 1987; Cho et al., 1992; Rapp and Lübken, 2003) and then results in the strong PMSE backscatter.

Today it is well accepted that (P)MSE are closely connected to the existence of small ice particles in the $\sim 5-$ $100 \mathrm{~nm}$ size range. Part of these particles with radii $\geq 30 \mathrm{~nm}$ are also detected optically as noctilucent clouds (NLC), as polar mesospheric clouds (PMC) observed by satellites, or as backscatter signals by using lidars (Thomas and McKay, 1985; von Cossart et al., 1999; Baumgarten et al., 2008). The relation of PMSE with NLC, for instance, had been

Published by Copernicus Publications on behalf of the European Geosciences Union. 
demonstrated by von Zahn and Bremer (1999). The clouds appear in the summer mesopause region due to very low temperatures and a sufficient water vapour content. Hence, the radar echoes can provide information about these atmospheric parameters and can be used to display features of atmospheric dynamics. Reviews of the subject have been presented by Cho and Kelley (1993), Cho and Röttger (1997) and most recently by Rapp and Lübken (2004).

Mesosphere summer echoes at mid latitudes have been investigated so far only with VHF radars on frequencies near $50 \mathrm{MHz}$ and only at a few stations near $50^{\circ} \mathrm{N}$. They are less frequent and weaker than polar mesosphere summer echoes and their occurrence is normally limited to daylight hours (Czechowsky et al., 1979; Thomas et al., 1996; Zecha et al., 2003).

Far more summer echoes have been detected at polar latitudes. They have been observed mostly at northern latitudes between $60^{\circ} \mathrm{N}$ and $75^{\circ} \mathrm{N}$, and mostly with radars operating near $50 \mathrm{MHz}$ (e.g. Ecklund and Balsley, 1981; Czechowsky et al., 1989; Kirkwood et al., 1998; Bremer et al., 2006). In addition, observations for differing Bragg scales were reported at higher frequencies on $224 \mathrm{MHz}$ (Hoppe et al., 1988), on $933 \mathrm{MHz}$ (Röttger et al., 1990), and on $1.29 \mathrm{GHz}$ (Cho et al., 1992), as well as at lower frequencies on $15 \mathrm{MHz}$ (Ogawa et al., 2003) and on $3 \mathrm{MHz}$ (Bremer et al., 1996). In more recent years, PMSE were also detected in the Southern Hemisphere at $62^{\circ} \mathrm{S}-73^{\circ} \mathrm{S}$ (e.g. Woodman et al., 1999; Morris et al., 2004, 2007; Kirkwood et al., 2007).

In this paper, the occurrence of PMSE at very high latitudes is statistically analysed for the first time. We present the results of observations carried out at Longyearbyen, Svalbard $\left(78^{\circ} \mathrm{N}, 17^{\circ} \mathrm{E}\right)$ during the summer months of the years 1999-2001 and 2003-2004 using the SOUSY Svalbard Radar. After a brief description of the radar and the experiments in Sect. 2, the occurrence of PMSE and their variations in time and height are discussed in Sect. 3. Furthermore, the PMSE thickness and the multi-layered structure of PMSE are presented. Some concluding remarks follow in Sect. 4.

\section{Instrumentation and experiment configuration}

In 1998 the SOUSY Svalbard Radar (SSR) was installed on Svalbard to study the mesosphere, stratosphere and troposphere at very high northern latitudes (Czechowsky et al., 1998). Here other systems allowed collocated observations, such as using rockets and lidars (e.g. Lübken et al., 2004; Strelnikov et al., 2006). The radar system has been operated by the Max-Planck-Institut für Aeronomie KatlenburgLindau and by the University of Troms $\varnothing$ with substantial support by the Leibniz-Institut für Atmosphärenphysik Kühlungsborn.

The radar operates on 53.5 MHz. An almost circular array of 356 Yagi-antennas is used for both transmission and reception. Czechowsky et al. (1998) quote a one-way antenna gain of $33 \mathrm{~dB}$ and a half power beam width of $4^{\circ}$. Besides the vertical beam direction, it is possible to steer the beam by $5^{\circ}$ in a north-east, south-east, south-west and north-west direction. The transmitter operates with about $70 \mathrm{~kW}$ peak power and $4 \%$ duty cycle. For the mesosphere studies a $20-$ bit-complementary code of $2 \mu$ s baud length was applied allowing a height resolution of $300 \mathrm{~m}$. Coherent integrations were done online to reduce the data flow.

In this paper, only the results of measurements with the vertical beam are presented. The received power from this direction is usually expected to be the highest due to the known aspect sensitivity, as described in detail, e.g. in Czechowsky et al. (1988). In 1999-2001 eight original data dumps - each with 64 data point time series in which each data point results from 21 coherent integrations - were combined to get a resulting time resolution of four minutes. In 2002 suitable measurements were not carried out. In 2003-2004 the number of coherent integrations was reduced to 16 and the number of data points in one time series was extended to 128 . Only five time series were then combined resulting in a four minute resolution again. Hence, all the results presented in this paper are based on the same height and time resolutions.

The main radar system parameters and experiment configurations are summarized in Table 1.

Because the results of radar measurements depend on a lot of different technical radar parameters and experiment configuration factors, generally the comparison of radar measurements should be carried out on the basis of an absolute calibration (Latteck et al., 2007, 2008) to obtain the volume reflectivity. However, due to the similar configurations of the SSR during the considered years, for the purpose of this paper it is not strictly required to apply an absolute calibration. We are considering only the signal-to-noise ratio (SNR), which provides a qualitative measure of the PMSE signal occurrence. The occurrence rates $\mathrm{OR}\left(\mathrm{SNR}>\mathrm{SNR}_{\min }\right)$ of $\mathrm{PMSE}$ greater than a given threshold value $\mathrm{SNR}_{\min }$ are determined. This limit has been defined by $\mathrm{SNR}_{\min }=0 \mathrm{~dB}$ in the years 1999-2001, but it has been modified to $\mathrm{SNR}_{\min }=-10 \mathrm{~dB}$ in the years 2003 and 2004 when the $10 \mathrm{~dB}$ power amplifier was removed. These thresholds were found to be sufficient for eliminating very low and doubtful signals near the noise level and, therefore, to be favourable for obtaining significant and consistent information on the diurnal and seasonal characteristics of PMSE as well as on their vertical structure.

\section{Results and discussion}

In the height-time image plot in Fig. 1 we present the signalto-noise ratio (SNR) of a $24 \mathrm{~h}$ period on 20 July 2001 as a typical observation for this location. Echoes appear between $80 \mathrm{~km}$ and $92 \mathrm{~km}$ with signal-to-noise ratios up to $30 \mathrm{~dB}$. Over the whole day, they occur in nearly the same altitude range but show some pronounced variations in their morphology. Sometimes one continuous PMSE band is noticed 
Table 1. Technical radar parameters and experiment configuration.

\begin{tabular}{llll}
\hline SOUSY Svalbard Radar & \multicolumn{3}{c}{ Experiment configuration } \\
\hline Frequency & $53.5 \mathrm{MHz}$ & Beam directions & Vertical (N, S, E, W not used) \\
Peak power & $70 \mathrm{~kW}$ & Pulse length & $2 \mu \mathrm{s}$ \\
Duty cycle & $4 \%$ & Code & $20 \mathrm{bit}$ complementary code \\
Antenna elements & 356 & Altitude range & $76 \mathrm{~km}-96 \mathrm{~km}$ \\
Antenna beam width & $4^{\circ}$ & Height resolution & $300 \mathrm{~m}$ \\
Antenna gain & $33 \mathrm{~dB}$ & Time resolution & $4 \mathrm{~min}$ \\
\hline
\end{tabular}

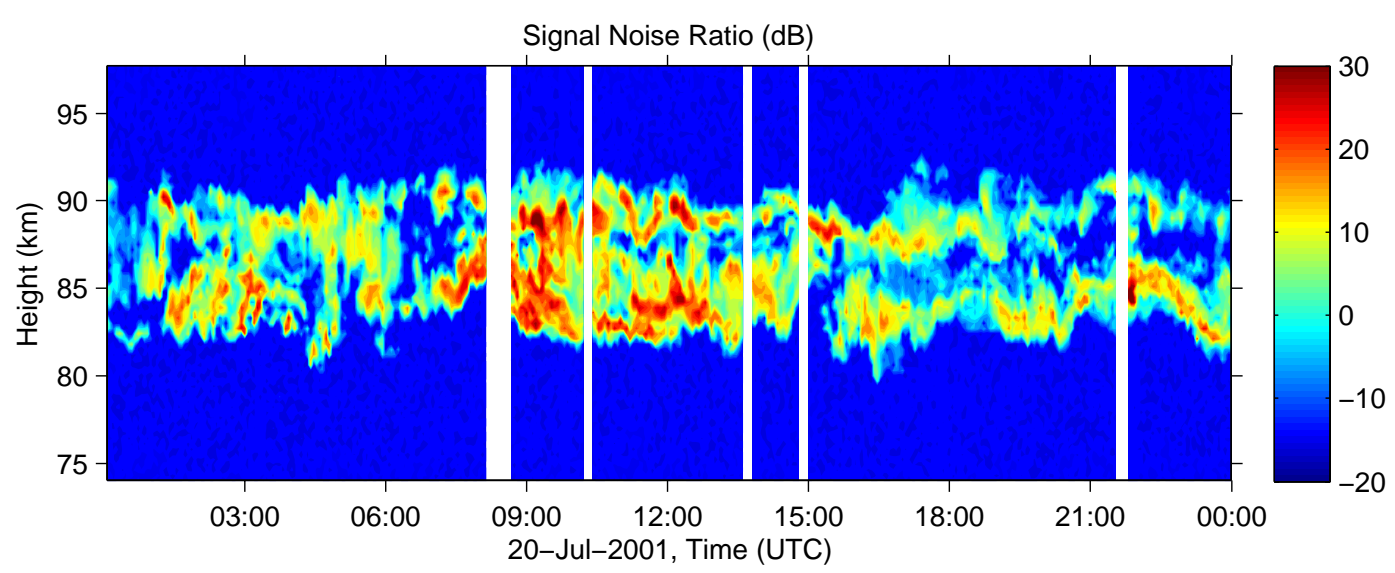

Fig. 1. Image plot of PMSE height-time intensity over Svalbard during a single day. The colours show the signal-to-noise ratio, white gaps mark short interruptions resulting from transmitter inhabits due to local air traffic security.

but more frequently the echoes appear in two or more vertically separated layers. Most of the strong echoes occur in the hours around 10:00 UTC (around 11:00 LT; UTC=68 min difference to real local time at Longyearbyen, $17^{\circ} \mathrm{E}$ ) when also the largest vertical extents of PMSE have been observed. In the following, the general details of these properties will be discussed.

\subsection{Seasonal variation}

Due to constraints in transmitter reliability and manpower limitations, it was not possible to sustain measurements every day during all five summers resulting in gaps of some days or weeks. These gaps differ from season to season and limit significant inter-annual comparisons. However, the sum of all measurements covers the complete summer season between beginning of May and beginning of September. This provides us to obtain mean PMSE characteristics for the years 1999-2004 at Svalbard.

Some properties of PMSE, such as day-to-day variations, could be smeared when averaging over a few years. Therefore, it is advisable to show these properties for a single season. Because measurements were most continuous in 2001 , we particularly concentrated on this year. Nearly continuous observations are available in the beginning, at the end, and during a long period of the main PMSE season in July and August. In this period the ROMA campaign took place at Svalbard which provided simultaneous temperature measurements by meteorological rockets and lidars. This allows new comparisons with PMSE. Hence, in this paper both fiveyear-averaging and single-year results are shown. Finally it should be noted that the presented results from 2001 do not differ very strongly from results of the other investigated years.

In Fig. 2 the occurrence rate of PMSE averaged over the measurement period during one day is presented. This is for all days from the beginning of May to the beginning of September and the height range $76 \mathrm{~km}$ to $96 \mathrm{~km}$. For each day it was tested for all 300-m range gates and for all 4min-timeslots whether the estimated SNR value was larger than the threshold value $\mathrm{SNR}_{\min }$. The sum of these timeslots events $\mathrm{N}_{\text {PMSE }}$ was compared with the sum of the time intervals $\mathrm{N}_{\mathrm{t}}$ when radar measurements were done. This yields the occurrence rate $\mathrm{OR}=100 \mathrm{~N}_{\mathrm{PMSE}} / \mathrm{N}_{\mathrm{t}}$ in percent.

PMSE occur from middle of May to end of August and in heights between approximately $80 \mathrm{~km}$ and $92 \mathrm{~km}$. The daily occurrence rates reach $50-80 \%$ in the center of this region and considerably smaller rates at the lower and upper $2-3 \mathrm{~km}$ and at the first and last 2-3 weeks. The occurrence gradient in altitude is somewhat steeper at the lower PMSE edge than 


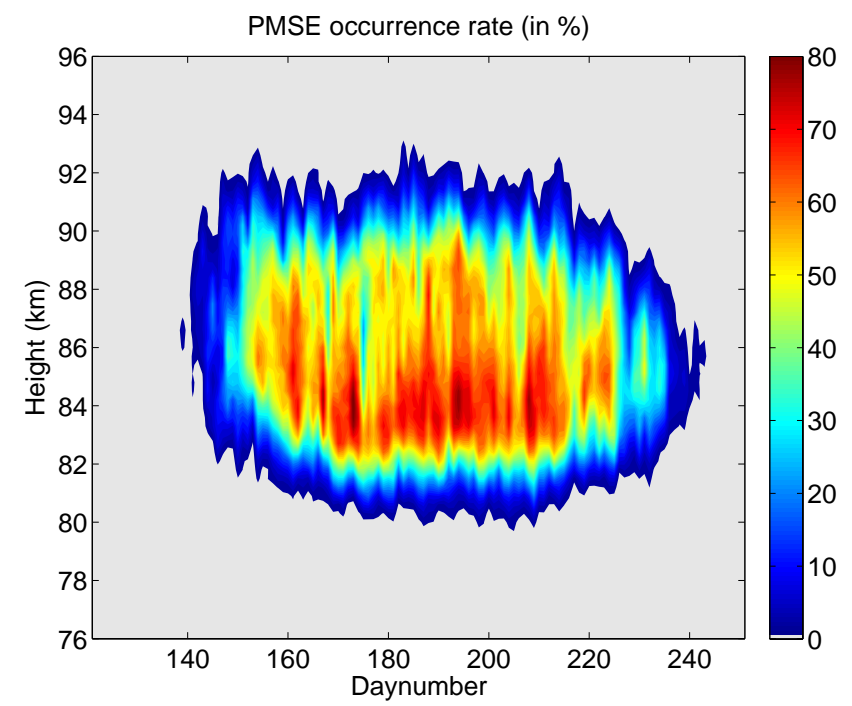

Fig. 2. Mean daily PMSE occurrence (averaged over 5 years) over Svalbard as a function of season and height. PMSE are present quasi exclusively between 80 and $92 \mathrm{~km}$ from mid May to end of August (daynumbers about 140-245).

at the upper PMSE edge, and the occurrence gradient in time is somewhat steeper at the beginning compared to the finishing period. The total altitude extension of PMSE grows rapidly in May, is fairly constant throughout June and July, and shrinks in August.

During the ROMA campaign, which was carried out from middle of July to middle of September 2001, PMSE were observed by radar and temperatures by meteorological rockets. Comparisons of results obtained by simultaneous measurements show good agreement between PMSE occurrence at height ranges, where the temperature is cold enough for the existence of ice particles $(120-150 \mathrm{~K})$. The seasonal and height variation of PMSE agrees well with the seasonal variation of supersaturation, which is deduced from measured temperatures and pressures, and water vapor mixing ratios from models (Lübken et al., 2004). These results are generally confirmed using the most recent available resonance lidar temperature measurements (Lautenbach et al., 2008; Lübken et al., 2009). The latter authors also showed that the uppermost portion of the supersaturated altitude range is void of PMSE due to the exponentially increasing kinematic viscosity with height. This efficiently destroys any small scale irregularities, and hence also Bragg-scale structures and PMSE (Lübken et al., 2009).

We now investigate the total occurrence rate, which we define as follows: It is searched for each 4-min-timeslot whether there is PMSE ( $\mathrm{SNR}>\mathrm{SNR}_{\min }$ ) within at least one $300 \mathrm{~m}$ range gate between $76 \mathrm{~km}$ and $96 \mathrm{~km}$ altitude. The upper panel in Fig. 3 shows the results related to the measurement time during each day of year.
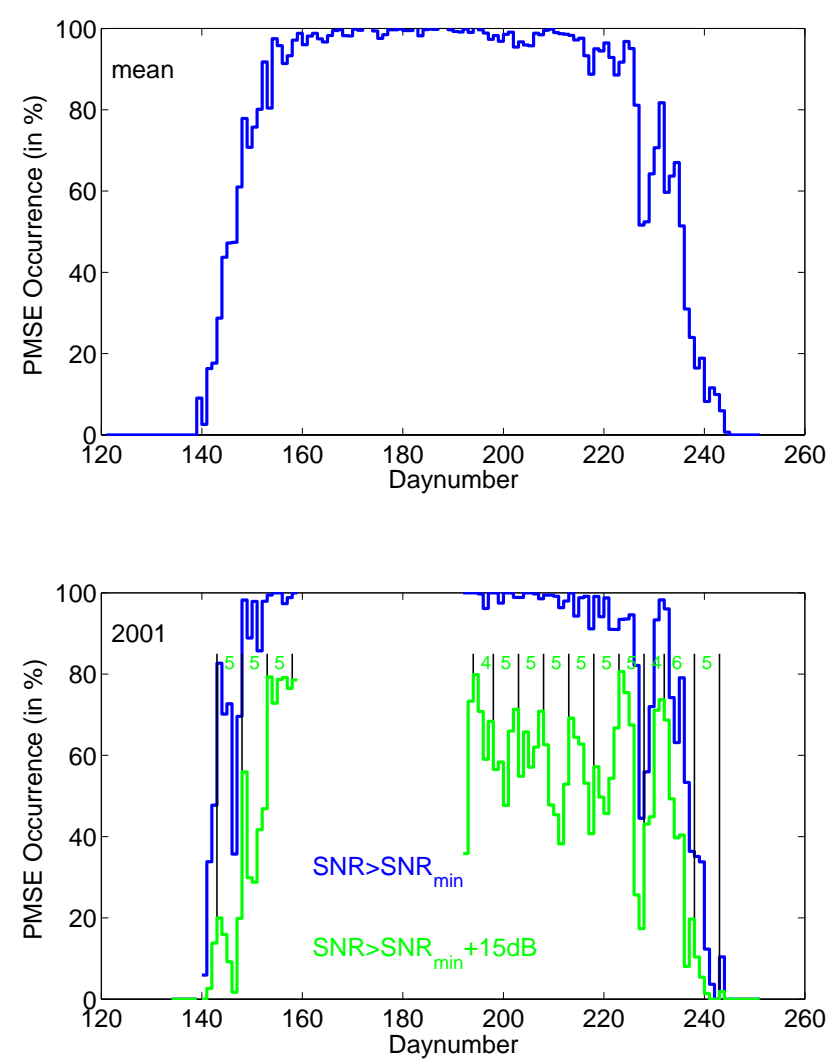

Fig. 3. Mean seasonal variations of daily total PMSE occurrence rates from SOUSY Svalbard Radar observations at Longyearbyen during five summers (upper panel) and the individual year 2001 (lower panel). The blue curve represents the development of the occurrence rate for all echoes with $\mathrm{SNR}>\mathrm{SNR}_{\min }$ and the green curve for the strong echoes with $\mathrm{SNR}>\mathrm{SNR}_{\min }+15 \mathrm{~dB}$. The threshold was assigned to $\mathrm{SNR}_{\min }=0 \mathrm{~dB}$ in the year 2001 .

The earliest PMSE was found on 18 May in 2004 and the latest PMSE on 31 August in 2000. At the beginning of the PMSE period the daily occurrence increased during the very short time of about two weeks from $0 \%$ to nearly $100 \%$. This means that the mean rate of occurrence increase from mid May to the beginning of June is about $7 \%$ per day. Subsequent to this period, for about 10 weeks PMSE are present almost all the time (i.e., the occurrence rate OR is nearly constant at $100 \%$ ) before the occurrence rate decreases in about three weeks to $0 \%$ again (about $-5 \%$ per day).

These characteristics are different to the seasonal PMSE occurrence in moderate polar and in mid latitudes. At those lower latitudes PMSE season starts and ends nearly at the same dates as in Svalbard, but increases/decreases more slowly and reaches lower maximum daily occurrence rates. For example, averaged over seven years, in Andenes $\left(69^{\circ} \mathrm{N}\right)$ the occurrence rate gradients are about $4 \%$ /day at the start and about $-3 \% /$ day at the end of the season. During June and July occurrence rates are near constant at $80 \%$ to $90 \%$. 

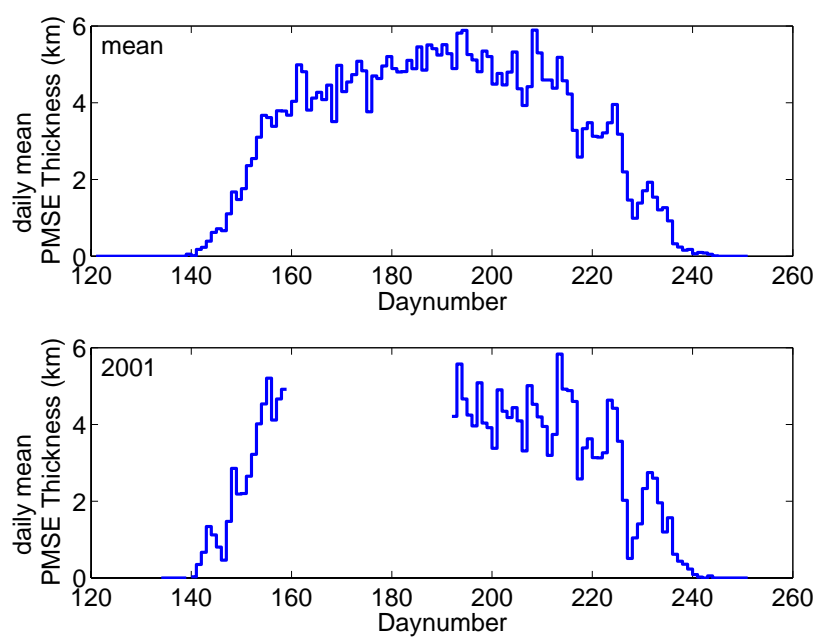

Fig. 4. Seasonal variation of daily mean PMSE thickness averaged over all PMSE events during five summers (upper panel) and during the year 2001 (lower panel).

Further to the south at Kühlungsborn $\left(54^{\circ} \mathrm{N}\right)$ OR drops to $7 \%$ for some days at end of June and beginning of July (Bremer et al., 2006).

We note that in general comparison of observations at different sites requires absolute calibration of the radars involved (Latteck et al., 2007). For the radars utilised here, however, system parameters are comparably similar (see Latteck et al., 1999, for the relevant technical parameters) so that an initial comparison seems to be acceptable. A more in depth quantitative comparison will be dealt within a different paper.

It is noticeable in the upper panel of Fig. 3 that the decrease is not steady. To show these potential variations more clearly, the seasonal development of the occurrence rates $\mathrm{OR}\left(\mathrm{SNR}>\mathrm{SNR}_{\min }\right.$ with $\mathrm{SNR}_{\min }=0 \mathrm{~dB}$ as defined above $)$ in the individual year 2001 is displayed in Fig. 3 (lower panel, blue chart). The routine measurements are started at the beginning of May, are interrupted from middle of June to middle of July due to other radar experiments, and are continued from middle of July until beginning of September. It is shown that beside the rapid increase and decrease of the occurrence rate and the nearly constant $100 \%$ occurrence in June and July, there is an indication of a quasi-periodic variation of the occurrence rate.

Instead of considering all PMSE-detections we may also investigate a subset of the observation which we call the "strong events" and which we define with a threshold of $\mathrm{SNR}_{\min }=15 \mathrm{~dB}$. The total OR for this high threshold is displayed as the green curve in the lower panel of Fig. 3. Here, even in June and July, the maximum occurrence rates do not reach $100 \%$. However, it becomes more evident that indications of periodic variations in the total OR appear during

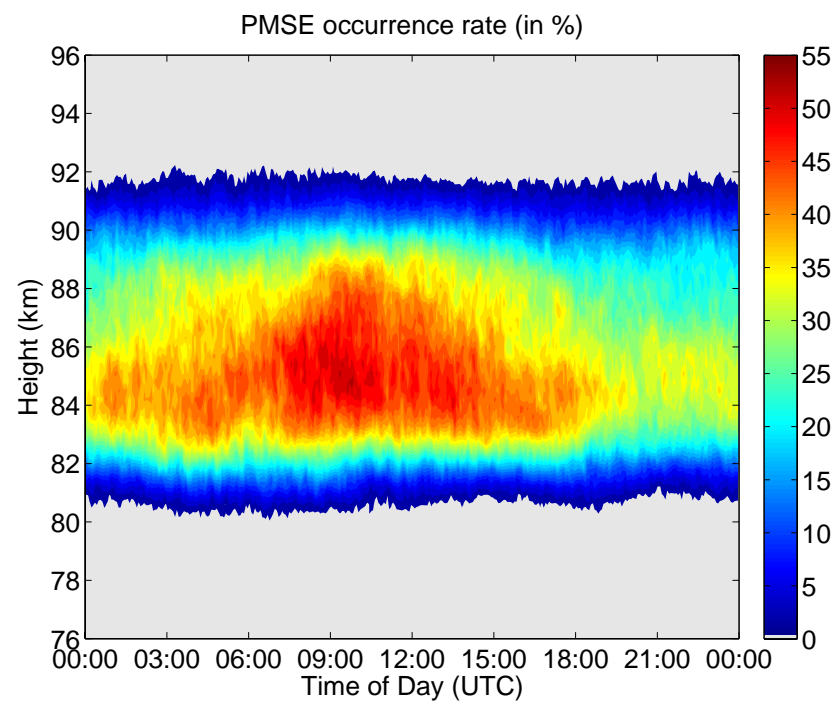

Fig. 5. Mean PMSE occurrence as a function of height and time. All mesosphere measurements during the summers 1999-2001 and 2003-2004 were analysed and combined. The maximum PMSE occurrence rate is observable over a wide height range (about 83 $89 \mathrm{~km})$ at the same time (09:00-10:00 UTC).

the whole summer. The period of this variation is about five days. These quasi-5-day-distances are marked by the black lines at the relative maxima of the total OR in Fig. 3. Similar characteristics were found in all the other observation years. Hence, it can be assumed that this quasi-5-day variation is a pronounced feature of PMSE occurrence at Svalbard.

To get information about the mean vertical extent of the PMSE for each 4-min-slot, all 300-m-resolution height bins with $\mathrm{SNR}>\mathrm{SNR}_{\min }$ are counted and averaged over the complete measurement time during the day. Figure 4 (upper panel) shows the mean seasonal variation of these data hereafter called PMSE thickness - for the years 1999-2004 except 2002.

At the beginning of the summer season, PMSE layers are thin but the thickness grows rapidly and reaches $4-6 \mathrm{~km}$ mean values in June/July before it comes down to smaller values again at the end of the season (middle/end of August). The increase in the first 2 weeks and the decrease in the last 3 weeks of the PMSE season are about $+0.25 \mathrm{~km} /$ day and $-0.25 \mathrm{~km} /$ day, respectively. Although the total occurrence rate is practically $100 \%$ in the 10 weeks in-between (Fig. 3) the PMSE thickness varies between about $4 \mathrm{~km}$ and $6 \mathrm{~km}$.

In order to avoid averaging out potential periodicities, individual years must be considered. Here, we focus on the year 2001. The seasonal variation of PMSE thickness of this year is displayed in Fig. 4. It is readily identifiable that all the time variations appear with a period of about 5 days again. 


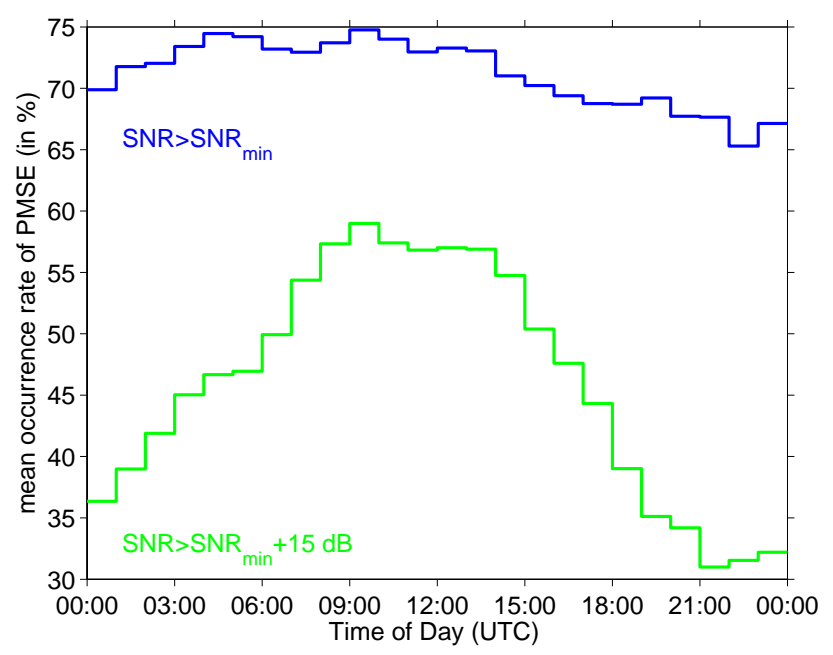

Fig. 6. Mean diurnal variation of PMSE occurrence during five summers between 1999 and 2004 for different thresholds: $\mathrm{SNR}>\mathrm{SNR}_{\min }$ (blue curve) and $\mathrm{SNR}>\mathrm{SNR}_{\min }+15 \mathrm{~dB}$ (green curve, indicating strong events).

\subsection{Diurnal variation}

The mean diurnal variation of the PMSE occurrence during the five PMSE seasons based on the maximum height and time resolution is shown in Fig. 5 as a function of time and altitude. PMSE have been observed between $80 \mathrm{~km}$ and $92 \mathrm{~km}$. The diurnal variation in the lower and upper $2 \mathrm{~km}$ of this range is not well pronounced but in the middle part it is identifiable that most PMSE appear between 03:00 UTC and 18:00 UTC with a clear maximum at 09:00-10:00 UTC. The daily minimum is noticeable near 21:00-22:00 UTC. These temporal characteristics can be observed more or less pronounced at all altitudes.

Figure 6 displays the diurnal variation of the mean total occurrence rate. Separately for each hour of the day it was counted, how often PMSE with $\mathrm{SNR}>\mathrm{SNR}_{\min }$ (blue curve) occur in at least one range gate in the 4-min bins and then this value was related to all measurements in this hour. The diagram shows a very slight variation with a maximum at 09:00-10:00 UTC and minimum at 22:00-23:00 UTC. The mean value of about $70 \%$ here is certainly influenced by the length of the averaging period, i.e., it certainly matters whether the initial rise and final decay of the season are included or not.

If only strong echoes are regarded, for example PMSE with $\mathrm{SNR}>\mathrm{SNR}_{\min }+15 \mathrm{~dB}$ as demonstrated by the green line in Fig. 6, the variation with the maximum at 09:0010:00 UTC and the minimum at 21:00-22:00 UTC is more pronounced. It shows that before and around noon more strong echoes appear and less in in the evening.

The mean diurnal variations of PMSE thickness is displayed in Fig. 7 with a one-hour-resolution. This value for

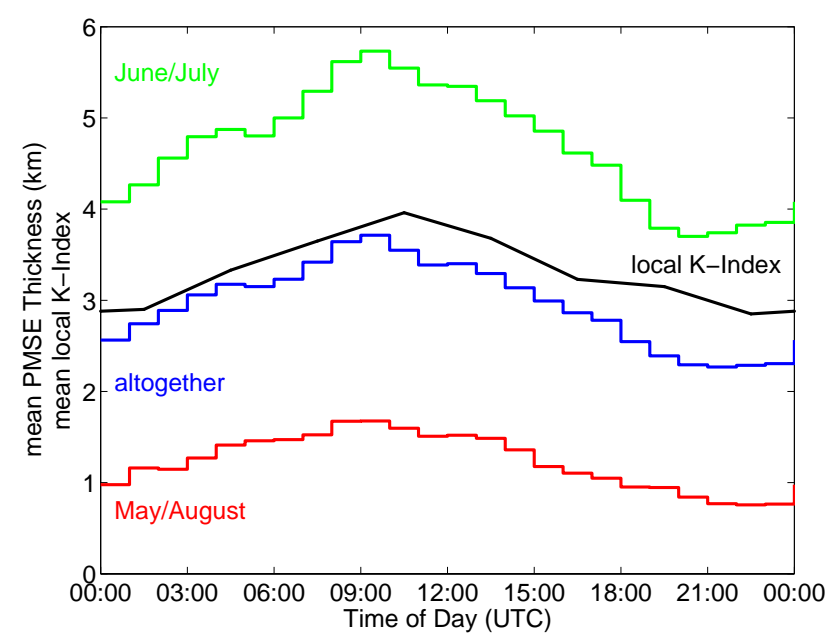

Fig. 7. Colored lines: Mean diurnal variation of PMSE thickness averaged over all PMSE events during five summers between 1999 and 2004 for the periods May/August (red), June/July (green) and the complete summer season (blue). The mean K-index for geomagnetic activity at Longyearbyen (averaged over the complete summer seasons of five years) shows the same diurnal variation (black line).

the vertical extent of PMSE is shown for the complete measurement season (blue curve), for May and August as the beginning and the end of the season (red curve) and for June and July when PMSE occur nearly permanently (green curve). It is noticeable that all the time PMSE are most extended at 09:00-10:00 UTC and narrowest near 21:0022:00 UTC. Hence, this characteristic is not a function of the season. The mean daily times for maximum and minimum of the PMSE thickness and of the PMSE occurrence are the same.

These variations are different to observations at radar stations at other latitudes. Kühlungsborn $\left(54^{\circ} \mathrm{N}\right)$, Andenes $\left(69^{\circ} \mathrm{N}\right)$ and Longyerabyen $\left(78^{\circ} \mathrm{N}\right)$ are located nearly at the same longitude $\left(12^{\circ} \mathrm{E}-17^{\circ} \mathrm{E}\right)$ with nearly the same timeshift from UTC to real local time (48-68 min), but PMSE investigations at these stations display very different diurnal variations. In Andenes PMSE occurrence show a clear maximum at 12:00-13:00 UTC and a pronounced minimum at about 18:00-20:00 UTC. Also a secondary maximum occurs near the midnight/early morning hours (Hoffmann et al., 1999). In Kühlungsborn the MSE maximum at 11:00 UTC fits very well the local high noon (Zecha et al., 2003) when the ionisation of nitric oxide (NO) by solar Lyman $\alpha$ radiation is maximum (e.g. Brasseur and Solomon, 1984). During nighttime, ionisation is too small for MSE creation except for the rare occasions that particle precipitation happens during extra-ordinary strong ionospheric disturbances at the midlatitude station (Zecha et al., 2003). According to Goldberg et al. (2001) and Rapp et al. (2002) a threshold value of about $500 \mathrm{el} . / \mathrm{cm}^{3}$ is necessary for MSE. 
Over Svalbard daylight conditions are permanent during the summer and the solar zenith angle varies only slightly (maximum $24^{\circ}$ difference from local midnight to local high noon). The absolute solar zenith angle reaches a minimum of about $55^{\circ}$ at high noon at summer solstice and a maximum of about $90^{\circ}$ at midnight at end of August. Hence, there is only a minor diurnal solar influence. However, the PMSE occurrence is also influenced by particle precipitation events (e.g. Bremer et al., 2001; Barabash et al., 2002; Morris et al., 2005) which are closely related to geomagnetic variations. The geomagnetic local K-index of Longyearbyen, Svalbard, in a three-hour-resolution (provided by the Troms $\varnothing$ Geophysical Observatory, http://geo.phys.uit.no/geomag.html) averaged over the period from May to August of the five years (black curve) is displayed also in Fig. 7. It shows the same diurnal variations with a maximum between 09:00 and 12:00 UTC and a minimum between 21:00 and 24:00 UTC as the PMSE occurrence rates and PMSE thickness. This could be a hint to the prominent influence of electron density enhancements during auroral disturbances on PMSE at Svalbard.

\subsection{Height distribution and layering}

The cumulative height distribution of PMSE occurrence rate is shown in Fig. 8 where the seasonally integrated occurrence time for PMSE is plotted in dependence on height (blue curve). PMSE occur most frequently in the center of the height region $(\sim 82-88 \mathrm{~km})$ with a peak near $85 \mathrm{~km}$. They are quite rare $(<10 \%)$ below $81 \mathrm{~km}$ and above $91 \mathrm{~km}$. Practically no coherent echoes were observed below $80 \mathrm{~km}$ and above $92 \mathrm{~km}$. These facts are similar to the results from middle and moderate polar latitudes (e.g. Zecha et al., 2003; Latteck et al., 2007). However, in contrast to these locations the PMSE distribution over Svalbard is not symmetrically arranged with height around its maximum but shows a "shoulder" at heights above the maximum. This is a typical feature which has been observed in all years and which has been reported also in earlier works (Rüster et al., 2001; Lübken et al., 2004).

Due to the seasonal variations, the presented PMSE occurrence rates as a function of height depend on the averaging period, the mean occurrence rates are greater in June and July (green curves) than in May and August (red curves). The limitation of PMSE to the region between $80 \mathrm{~km}$ and $92 \mathrm{~km}$ is obvious for every month. The height of maximum occurrence varied from $86 \mathrm{~km}$ in May to $84 \mathrm{~km}$ in July, which suggest a mean downward movement of PMSE during the season. Investigations of the daily mean PMSE heights of the single years have shown downward movements from mid May to end August with maximum $34 \mathrm{~m} /$ day in 2001 and minimum $0 \mathrm{~m} /$ day in 2004 (not displayed here). The maximum PMSE occurrence for the complete PMSE season is near $85 \mathrm{~km}$ and comparable to the maximum at mid and lower polar latitudes (e.g. Zecha et al., 2003; Latteck

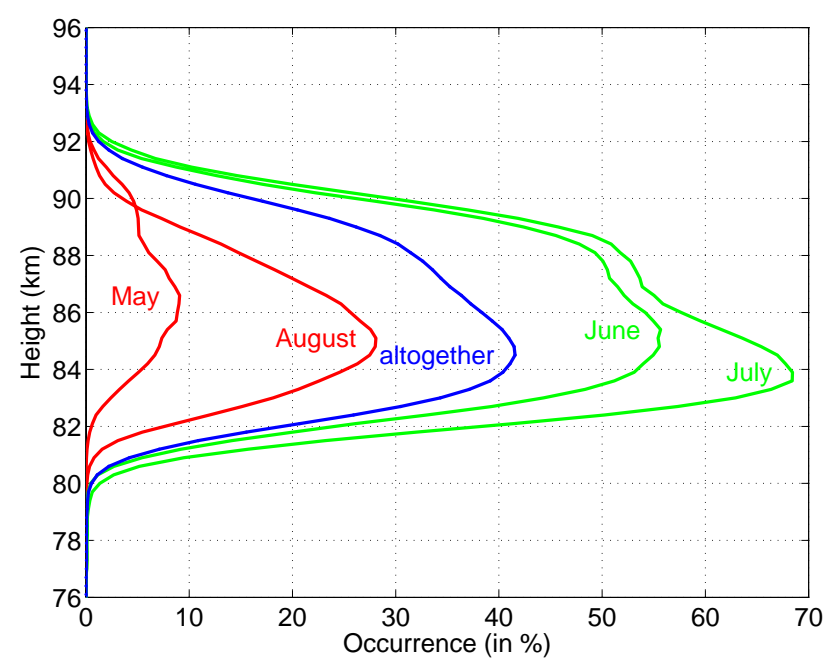

Fig. 8. Mean height dependence of the PMSE occurrence rate (averaged over five years) for the periods May and August (red), June and July (green), and the complete summer season (blue).

et al., 2007). The "shoulder" is especially prominent in June and July (green curves), it seems that especially during this time the PMSE are not symmetrically distributed around the height of the maximum occurrence.

To interpret this characteristic, it has to be remarked that the PMSE often occur not continuously over the complete altitude range but also in some distinct separated layers. This layer structure is very common for PMSE observations over Svalbard (Rüster et al., 2001; Röttger, 2003). The latter author evaluated case studies and reported up to three or sometimes even more PMSE structures separated on the average by less than a few kilometers in height.

Also in other latitudes such layering was observed. For example Hoffmann et al. $(2005,2008)$ performed in-depth statistical analyses of multiple layer PMSE events observed at Andenes. They quote that about $50 \%$ of all PMSE events are single layered and $50 \%$ are multiple layered at $69^{\circ} \mathrm{N}$. The mean heights of the maximum of the height distributions are given in this papers with about $85 \mathrm{~km}$ for single layers, about $83 \mathrm{~km}$ for the lowest layers and about $86 \mathrm{~km}$ for the second layers in the multiple layer cases.

In the following, we will investigate the statistics of such events at Svalbard based on the five years of observations. To determine the layer structure, the individual vertical profiles with the four minute time resolution and $300 \mathrm{~m}$ height resolution are analysed. The layers are identified by echoes greater than the general threshold $\left(\mathrm{SNR}>\mathrm{SNR}_{\min }\right)$ and are separated by the detection of a relative minimum of SNR which is between relative maxima with height and at least $10 \mathrm{~dB}$ below them. For each layer the altitude with the maximum SNR gives the corresponding height value. This procedure is fairly similar to that reported by Hoffmann et al. (2005) and hence allows a comparison of the results. 

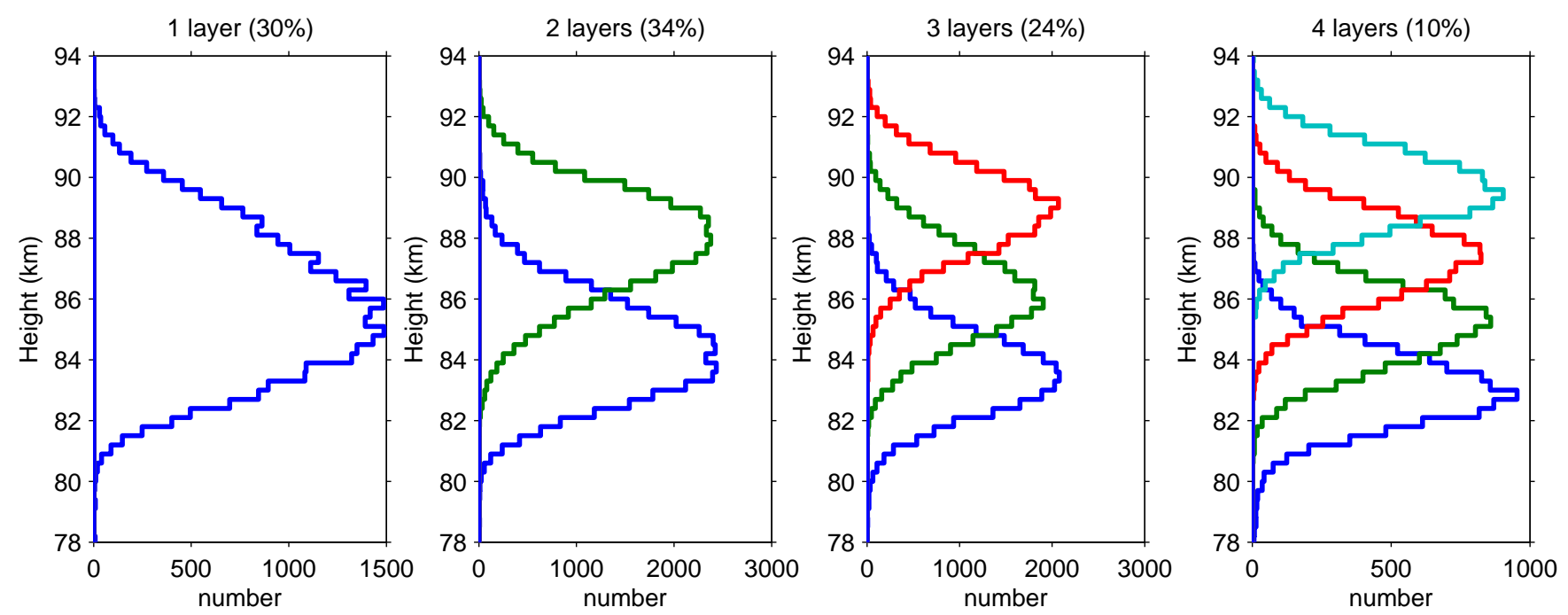

Fig. 9. For 1 to 4 layers structure occurrence (left panel to right panel, respectively): mean height dependence of the maxima of the first (blue), second (green), third (red) and forth (cyan) of all layers, averaged over five summers between 1999 and 2004.

In Svalbard the number of single layer events is only about $30 \%$. They are nearly symmetrically distributed between $80 \mathrm{~km}$ and $92 \mathrm{~km}$ around a maximum near $85 \mathrm{~km}$ as shown in the left panel of Fig. 9. Because the number of multiple layer cases outweighs the single layer cases they are further split into cases of two layers (34\%), three layers (24\%) and four layers (10\%) as shown in the other panels of Fig. 9. The small remainder of about $2 \%$ is more than four layer events and are not shown here. If there are two layers then the maximum of the lower layers (blue curve) is near $84 \mathrm{~km}$ and the maximum of the higher layers (green curve) near $88 \mathrm{~km}$. For the three layer events the maxima of the height distributions are at about 83,86 and $89 \mathrm{~km}$ and for the four layer events they are at about $83,85,88$ and $90 \mathrm{~km}$. If multiple layers occur, than it is remarkable that in each case the distributions of the layers have nearly the same maximum value, nearly the same gaussian shape with nearly the same variance, and the heights of the maxima are nearly equally spaced.

The complete height distribution as displayed in Fig. 8 is related to a combination of all height distributions shown in Fig. 9. Its shape can be explained by the different appearance frequencies and vertical extensions of the various layers. The pronounced "shoulder" in June and July give a hint that in this period the occurrence of multiple layers is higher than in May and August.

To explain this fact in detail in Fig. 10, the seasonal variations of single, double, tripple and quadruple layering are shown for the year 2001. The diagram for single layers (upper left panel) shows that really the occurrence rate of these events starts at $100 \%$ in mid May, falls down rapidly to about $10 \%$, varied around 10-20\% during June and July, and rises up to $100 \%$ again in August. The other cases (upper right, lower left, and lower right panel for double, triple, and quadruple layering, respectively) show the opposite characteristic. The curves rise up in the first 2 weeks of the PMSE appearance, remain at a relative constant level in June/July and fall down in August. This confirms the assumption that the layering is markedly dependent on season. Investigations for June and July of all five summers 1999-2001 and 20032004 show that a single layer appears only in about $20 \%$ of all PMSE events in this period. The relations for double, triple and quadruple layers are then $36 \%, 28 \%$ and $12 \%$, respectively.

What could be the reason for this layering. Hoffmann et al. $(2005,2008)$ found for the latitude of $69^{\circ} \mathrm{N}$ an enhanced formation of multiple PMSE layer structures in the presence of long period gravity waves and tidal activity as expected from their own microphysical modeling based on Rapp et al. (2003). They proposed that the observed multiple layer structures are mainly caused by layering of ice particles due to subsequent nucleation cycles in the cold phases of long period gravity waves. They have confirmed this idea by comparisons from multiple layer occurrence with estimations of gravity waves based on continuous MF radar wind measurements at the same location. Some authors have discussed the contribution of different physical parameters on the morphology of PMSE, like the general thermal structure, Kelvin-Helmholtz-instabilities, turbulence, tides and gravity waves (e.g. Röttger, 1994; Klostermeyer, 1997; Hill et al., 1999; Morris et al., 2006). All these physical processes could be reasons for the occurrence of multiple layers at $78^{\circ} \mathrm{N}$. However, more investigations are necessary to confirm this and the results will be published in the future.

Another property of seasonal variations described in Sect. 3.1 is also eye-catching in the curves of Fig. 10. All of the charts of the seasonal layering are not smooth but show 

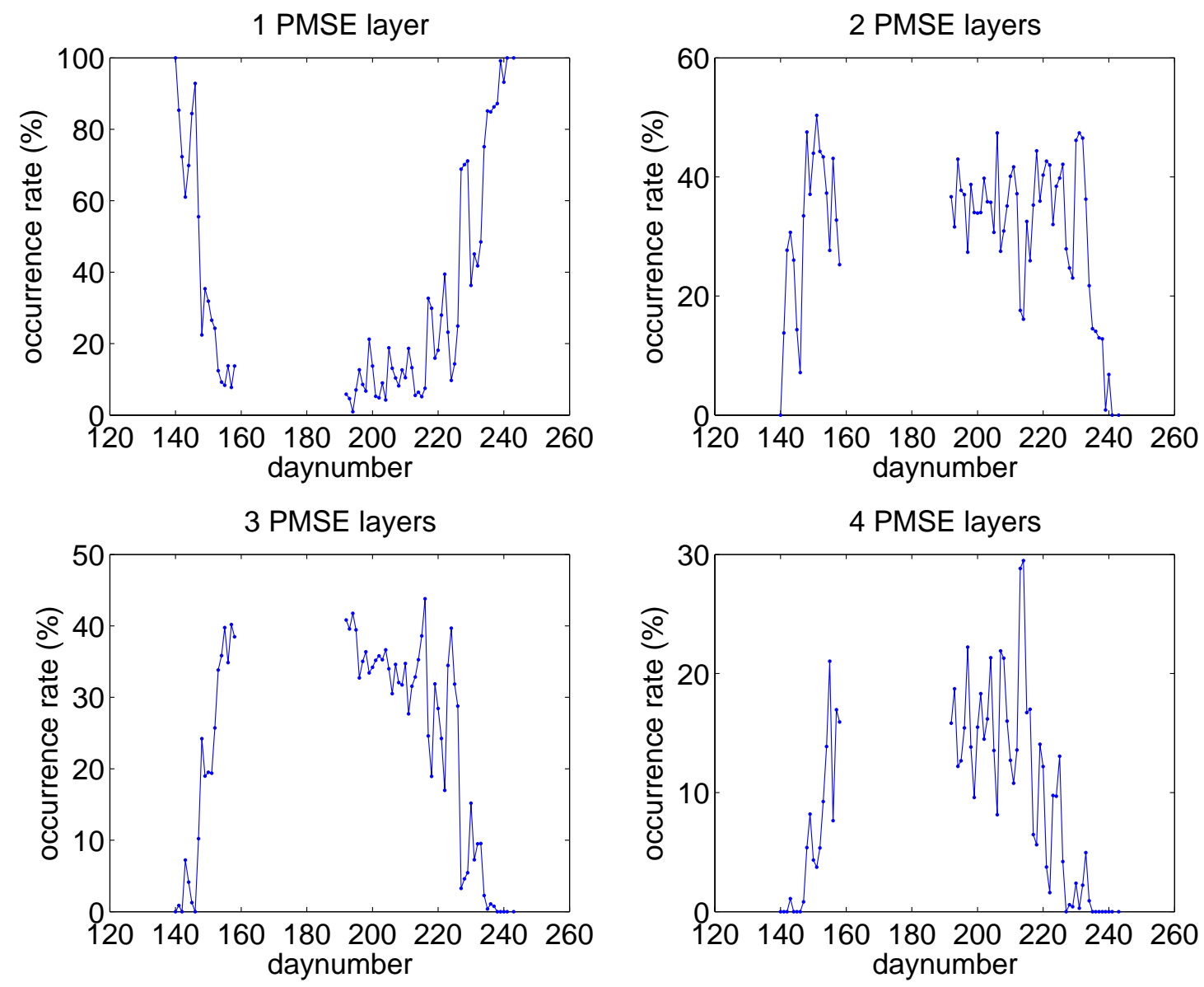

Fig. 10. Seasonal variation of the relative rate for the occurrence of 1, 2, 3 or 4 layers in all PMSE events during the year 2001.

some variations with a period of about five days. Five-day periodicities have been reported also in previous works about the mesopause region by some authors (e.g. Kirkwood et al., 1998; Kirkwood and Stebel, 2003; von Savigny et al., 2007; Merkel et al., 2008). They reported that observations of temperatures, zonal wind, NLC, PMSE and PMC show variations correlating with the passage of 5-day planetary waves. These waves could also be the reason for the strong 5-dayvariations in PMSE occurrence, thickness and layering over Svalbard.

The long data sets obtained with the SSR between 1999 and 2004 which we have treated here statistically can form a basis for further investigations of these long-period waves. The variations in PMSE occurrence and the analysis of wind profiles, which are available due to the SSR beam steering, could verify the potential modulation by the long-period waves at these high polar latitudes. This issue will be left for a future investigation.

\section{Conclusions}

Extensive VHF radar observations at $53.5 \mathrm{MHz}$ have been carried out at $78^{\circ} \mathrm{N}$ at Svalbard with the SOUSY Svalbard Radar during five summer seasons between 1999 and 2004. One of the main aims of this project was the investigation of the occurrence of polar mesosphere summer echoes at this very high latitude. It is worth mentioning that measurements are available for every individual day between 2 May and 9 September at least in one of the five years. Based on the analysis of more than $9300 \mathrm{~h}$ of measurements with more than $6600 \mathrm{~h}$ when PMSE were detected, the following results have been derived:

PMSE occur from mid May until end of August. They were detected in summer during a period of more than two months nearly continuously. Hence, the conditions for the existence of charged ice particles exist permanently in June and July. Also the PMSE thickness and the PMSE layering are on an almost constant level during this time. However, all parameters show variations with a period of about 5 days which could be attributed to 5-day planetary waves. 
Diurnal variations of PMSE occurrence and thickness are dominated by a maximum around 09:00-11:00 UTC and a minimum around 21:00-23:00 UTC. This could be caused by precipitating particles as the geomagnetic impact shows in average the same variation.

A prominent property of PMSE at Svalbard is the layering of the echoes. The relative occurrence of single, double and triple layer events amount to about one third each, in June and July the number of single layers is only as little as $20 \%$. Because the multiple layers are more often than in moderate and middle latitudes, the combined height distribution also differs from the other latitudes. It is not symmetrically arranged around the maximum value near $85 \mathrm{~km}$, but shows a characteristic "shoulder" above the maximum.

Hence, the common occurring characteristics of PMSE are observable at Svalbard too, but they are much more pronounced than comparable characteristics of mesosphere summer echoes in moderate polar latitudes and in middle latitudes. The utilisation of this fact could give advantages in further investigations regarding the creation and development of PMSE.

Acknowledgements. The SOUSY Svalbard Radar was operated by the Max-Planck-Institut für Aeronomie Katlenburg-Lindau and by the University of Troms $\varnothing$ with support by the Leibniz-Institut für Atmosphärenphysik Kühlungsborn. Many scientists and engeneering staff were involved in activities relating to the radar. Representatively the authors would like to thank P. Czechowsky and colleagues, C. Hall and colleagues, J. Trautner, N. Engler, and J.S. Chen, for their permission to use data, commitment and support in organising, system operating and data collecting, respectively.

Topical Editor U.-P. Hoppe thanks M. Rietveld and another anonymous referee for their help in evaluating this paper.

\section{References}

Barabash, V., Kirkwood, S., and Chilson, P. B.: Are variations in PMSE intensity affected by energetic particle precipitation?, Ann. Geophys., 20, 539-545, 2002,

http://www.ann-geophys.net/20/539/2002/.

Baumgarten, G., Fiedler, J., Lübken, F.-J., and von Cossart, G.: Particle properties and water content of noctilucent clouds and their interannual variation, J. Geophys. Res., 113, D06203, doi: 10.1029/2007JD008884, 2008.

Brasseur, G. and Solomon, S.: Aeronomy of the middle atmosphere, D. Reidel, Norwell, Mass., 1984.

Bremer, J., Hoffmann, P., Manson, A. H., Meek, C. E., Rüster, R., and Singer, W.: PMSE observations at three different frequencies in northern Europe during summer 1994, Ann. Geophys., 14, 1317-1327, 1996, http://www.ann-geophys.net/14/1317/1996/.

Bremer, J., Hansen, T., Hoffmann, P., and Latteck, R.: Dependence of polar mesosphere summer echoes on solar and geomagnetic activity, Adv. Space Res., 28, 1071-1076, 2001.

Bremer, J., Hoffmann, P., Höffner, J., Latteck, R., Singer, W., Zecha, M., and Zeller, O.: Long-term changes of mesospheric summer echoes at polar and middle latitudes, J. Atmos. So- lar Terr. Phys., 68, 1940-1951, doi:10.1016/j.jastp.2006.02.012, 2006.

Cho, J. Y. N. and Kelley, M. C.: Polar mesosphere summer radar echoes: Observations and current theory, Rev. Geophys., 31, 243-265, doi:10.1029/93RG01535, 1993.

Cho, J. Y. N. and Röttger, J.: An updated review of polar mesosphere summer echoes: Observation, theory, and their relationship to noctilucent clouds and subvisible aerosols, J. Geophys. Res., 102, 2001-2020, 1997.

Cho, J. Y. N., Hall, T. M., and Kelley, M. C.: On the role of charged aerosols in polar mesosphere summer echoes, J. Geophys. Res., 97, 875-886, 1992.

Czechowsky, P., Rüster, R., and Schmidt, G.: Variations of mesospheric structures in different seasons, Geophys. Res. Lett., 6, 459-462, 1979.

Czechowsky, P., Reid, I. M., and Rüster, R.: VHF radar measurements of the aspect sensitivity of the summer polar mesopause echoes over Andenes $\left(69^{\circ} \mathrm{N}, 16^{\circ} \mathrm{E}\right)$, Norway, Geophys. Res. Lett., 15(11), 1259-1262, 1988.

Czechowsky, P., Reid, I. M., Rüster, R., and Schmidt, G.: VHF radar echoes observed in the summer and winter polar mesosphere over Andoya, Norway, J. Geophys. Res., 94(D4), 51995217, 1989.

Czechowsky, P., Klostermeyer, J., Röttger, J., Rüster, R., and Schmidt, G.: The SOUSY-Svalbard-Radar for middle and lower atmosphere research in the polar region, Proceedings of the Eighth Workshop on Technical and Scientific Aspects of MST Radar (MST8), Bangalore, India, SCOSTEP Secret., pp. 318321, 1998.

Ecklund, W. L. and Balsley, B. B.: Long-term observations of the arctic mesosphere with the MST radar at Poker Flat, Alaska, J. Geophys. Res., 86, 7775-7780, 1981.

Goldberg, R., Pfaff, R., Holzworth, R., Schmidlin, F.-J., Voss, H., Tuzzolino, A., Croskey, C., Mitchell, J., Friedrich, M., Murtagh, D., Witt, G., Gumbel, J., von Zahn, U., Singer, W., and Hoppe, U.-P.: DROPPS: A study of the polar summer mesosphere with rocket, radar and lidar, Geophys. Res. Lett., 28, 1407-1410, 2001.

Hill, R. J., Gibson-Wilde, D. E., Werne, J. A., and Fritts, D. C.: Turbulence-induced fluctuations in ionization and application to PMSE, Earth Plan. Space, 51, 499-513, 1999.

Hoffmann, P., Singer, W., and Bremer, J.: Mean seasonal and diurnal variations of PMSE and winds from 4 years of radar observations at ALOMAR, Geophys. Res. Lett., 26, 1525-1528, 1999.

Hoffmann, P., Rapp, M., Serafimovich, A., and Latteck, R.: On the occurrence and formation of multiple layers of polar mesosphere summer echoes, Geophys. Res. Lett., 32, L05812, doi:10.1029/ 2004GL021409, 2005.

Hoffmann, P., Rapp, M., Fiedler, J., and Latteck, R.: Influence of tides and gravity waves on layering processes in the polar summer mesopause region, Ann. Geophys., 26, 4013-4022, 2008, http://www.ann-geophys.net/26/4013/2008/.

Hoppe, U.-P., Hall, C., and Röttger, J.: First observation of summer polar mesosphere backscatter with a $224 \mathrm{MHz}$ radar, Geophys. Res. Lett., 15, 28-31, 1988.

Kelley, M. C., Farley, D. T., and Röttger, J.: The effect of cluster ions on anomalous VHF backscatter from the summer polar mesosphere, Geophys. Res. Lett., 14, 1031-1034, 1987.

Kirkwood, S. and Stebel, K.: Influence of planetary waves on noc- 
tilucent cloud occurrence over NW Europe, J. Geophys. Res., 108, 8440, doi:10.1029/2002JD002356, 2003.

Kirkwood, S., Barabash, V., Chilson, P., Réchou, A., Stebel, K., Espy, P., Witt, G., and Stegman, J.: The 1997 PMSE season - its relation to wind, temperature and water vapour, Geophys. Res. Lett., 25, 1867-1870, doi:10.1029/98GL01243, 1998.

Kirkwood, S., Wolf, I., Nilsson, H., Dalin, P., Mikhaylova, D., and Belova, E.: Polar mesosphere summer echoes at Wasa, Antarctica $\left(73^{\circ} \mathrm{S}\right)$ : First observations and comparison with $68^{\circ} \mathrm{N}$, Geophys. Res. Lett., 34, L15803, doi:10.1029/2007GL030516, 2007.

Klostermeyer, J.: A height- and time-dependent model of polar mesosphere summer echoes, J. Geophys. Res., 102, 6715-6727, 1997.

Latteck, R., Singer, W., and Bardey, H.: The ALWIN MST radar: Technical design and performances, pp. 179-184, Eur. Space Agency, Neuilly, France, 1999.

Latteck, R., Singer, W., Morris, R. J., Holdsworth, D. A., and Murphy, D. J.: Observation of polar mesosphere summer echoes with calibrated VHF radars at $69^{\circ}$ in the northern and southern hemispheres, Geophys. Res. Lett., 34, L14805, doi:10.1029/ 2007GL030032, 2007.

Latteck, R., Singer, W., Morris, R. J., Hocking, W. K., Murphy, D. J., Holdsworth, D. A., and Swarnalingam, N.: Similarities and differences in polar mesosphere summer echoes observed in the Arctic and Antarctica, Ann. Geophys., 26, 2795-2806, 2008, http://www.ann-geophys.net/26/2795/2008/.

Lautenbach, J., Höffner, J., Lübken, F.-J., and Zecha, M.: The thermal structure at the topside and above of polar mesosphere summer echoes over Spitsbergen $78^{\circ}$ N, Ann. Geophys., 26, 10831088, 2008, http://www.ann-geophys.net/26/1083/2008/.

Lübken, F.-J., Zecha, M., Höffner, J., and Röttger, J.: Temperatures, polar mesosphere summer echoes, and noctilucent clouds over Spitsbergen $\left(78^{\circ} \mathrm{N}\right)$, J. Geophys. Res., 109, D11203, doi: 10.1029/2003JD004247, 2004.

Lübken, F.-J., Lautenbach, J., Höffner, J., Rapp, M., and Zecha, M.: First continuous temperature measurements within polar mesosphere summer echoes, J. Atmos. Solar Terr. Phys., 71, 453-463, doi:10.1016/j.jastp.2008.06.001, 2009.

Merkel, A. W., Garcia, R. R., Bailey, S. M., and Russell III, J. M.: Observational studies of planetary waves in PMCs and mesospheric temperature measured by SNOE and SABER, J. Geophys. Res., 113, D14202, doi:10.1029/2007JD009396, 2008.

Morris, R. J., Murphy, D. J., Reid, I. M., Holdsworth, D. A., and Vincent, R. A.: First polar mesosphere summer echoes observed at Davis, Antarctica ( $\left.68^{\circ} \mathrm{S}\right)$, Geophys. Res. Lett., 31, L16111, doi:10.1029/2004GL020352, 2004.

Morris, R. J., Terkildsen, M. B., Holdsworth, D. A., and Hyde, M. R.: Is there a causal relationship between cosmic noise absorption and PMSE?, Geophys. Res. Lett., 32, L24809, doi: 10.1029/2005GL024568, 2005.

Morris, R. J., Murphy, D. J., Vincent, R. A., Holdsworth, D. A., Klekociuk, A. R., and Reid, I. M.: Characteristics of the wind, temperature and PMSE field above Davis, Antarctica, J. Atmos. Solar Terr. Phys., 68, 418-435, doi:10.1016/j.jastp.2005.04.011, 2006.

Morris, R. J., Murphy, D. J., Klekociuk, A. R., and Holdsworth, D. A.: First complete season of PMSE observations above Davis, Antarctica, and their relation to winds and temperatures, Geo- phys. Res. Lett., 34, L05805, doi:10.1029/2006GL028641, 2007.

Ogawa, T., Arnold, N. F., Kirkwood, S., Nishitani, N., and Lester,

M.: Finland HF and Esrange MST radar observations of polar mesosphere summer echoes, Ann. Geophys., 21, 1047-1055, 2003 ,

http://www.ann-geophys.net/21/1047/2003/.

Rapp, M. and Lübken, F.-J.: On the nature of PMSE: Electron diffusion in the vicinity of charged particles revisited, J. Geophys. Res., 108(D8), 8437, doi:10.1029/2002JD002857, 2003.

Rapp, M. and Lübken, F.-J.: Polar mesosphere summer echoes (PMSE): Review of observations and current understanding, Atmos. Chem. Phys., 4, 2601-2633, 2004, http://www.atmos-chem-phys.net/4/2601/2004/.

Rapp, M., Gumbel, J., Lübken, F.-J., and Latteck, R.: D region electron number density limits for the existence of polar mesosphere summer echoes, J. Geophys. Res., 107(D19), 4187, doi:10.1029/2001JD001323, 2002.

Rapp, M., Lübken, F.-J., Hoffmann, P., Latteck, R., Baumgarten, G., and Blix, T.: PMSE dependence on aerosol charge number density and aerosol size, J. Geophys. Res., 108(D8), 8441, doi:10.1029/2002JD002650, 2003.

Röttger, J.: Middle atmosphere and lower thermosphere processes at high latitudes studied with the EISCAT radar, J. Atmos. Terr. Phys., 56, 1173-1195, 1994.

Röttger, J.: About multiple layering and aspect sensitivity of polar mesosphere summer echoes, Proceedings of the Tenth International Workshop on Technical and Scientific Aspects of MST Radar (MST10), Radio Observatorio de Jicamarca and Universidad de Piura, Peru, pp. 54-57, 2003.

Röttger, J., Rietveld, M. T., LaHoz, C., Hall, C., Kelley, M. C., and Swartz, W. E.: Polar mesosphere summer echoes observed with the EISCAT 993-MHz radar and the CUPRI 46.9-MHz radar, their similarity to $224-\mathrm{MHz}$ radar echoes, and their relation to turbulence and electron density profiles, Radio Sci., 25, 671-687, 1990.

Rüster, R., Röttger, J., Schmidt, G., Czechowsky, P., and Klostermeyer, J.: Observations of mesospheric summer echos at VHF in the polar cap region, Geophys. Res. Lett., 28, 1471-1474, 2001.

Strelnikov, B., Rapp, M., Blix, T. A., Engler, N., Höffner, J., Lautenbach, J., Lübken, F.-J., Smiley, B., and Friedrich, M.: In situ observations of small scale neutral and plasma dynamics in the mesosphere/lower thermosphere at $79^{\circ} \mathrm{N}$, Adv. Space Res., 38, 2388-2393, 2006.

Thomas, G. E. and McKay, C. P.: On the mean particle size and water content of polar mesospheric clouds, Planet. Space Sci., 33, 1209-1224, doi:10.1016/0032-0633(85)90077-7, 1985.

Thomas, L., Marsh, A. K. P., Wareing, D. P., Astin, I., and Chandra, H.: VHF echoes from the midlatitude mesophere and the thermal structure observed by lidar, J. Geophys. Res., 101, 12867-12877, doi:10.1029/96JD00218, 1996.

von Cossart, G., Fiedler, J., and von Zahn, U.: Size distributions of NLC particles as determined from 3-color observations of NLC by ground-based lidar, Geophys. Res. Lett., 26, 1513-1516, 1999.

von Savigny, C., Robert, C., Bovensmann, H., Burrows, J. P., and Schwartz, M.: Satellite observaions of the quasi 5-day wave in noctilucent clouds and mesopause temperatures, Geophys. Res. Lett., 34, L24808, doi:10.1029/2007GL030987, 2007.

von Zahn, U. and Bremer, J.: Simultaneous and common-volume 
observations of noctilucent clouds and polar mesosphere summer echoes, Geophys. Res. Lett., 26, 1521-1524, 1999.

Woodman, R. F., Balsley, B. B., Aquino, F., Flores, L., Vazquez, E., Sarango, M., Huamann, M. M., and Soldi, H.: First observations of polar mesosphere summer echoes in Antarctica, J. Geophys. Res., 104, 22577-22590, doi:10.1029/1999JA900226, 1999.
Zecha, M., Bremer, J., Latteck, R., Singer, W., and Hoffmann, P.: Properties of midlatitude mesosphere summer echoes after three seasons of VHF radar observations at $54^{\circ} \mathrm{N}$, J. Geophys. Res., 108, 8439, doi:10.1029/2002JD002442, 2003. 